\title{
Genetic Variability and Association Studies on Bpt-5204 Based Rice Mutants under Saline Stress Soil
}

\author{
C. Prashanth ${ }^{1 *}$, K. Mahantashivayogayya ${ }^{1}$, J. R. Diwan ${ }^{2}$, \\ P. H. Kuchanur ${ }^{3}$ and J. Vishwanath ${ }^{1}$ \\ ${ }^{1}$ Agricultural Research Station, Gangavati, University of Agricultural Sciences, \\ Raichur - 584104, India. \\ ${ }^{2}$ Department of Genetics and Plant Breeding, College of Agriculture, \\ University of Agricultural Sciences, Raichur- 584104, India \\ ${ }^{3}$ Department of Genetics and Plant Breeding, College of Agriculture, \\ Bheemarayangudi, University of Agricultural Sciences, Raichur - 584104, India \\ *Corresponding author
}

\section{A B S T R A C T}

\section{Keywords}

Variability, BPT5204 mutants,

Association,

Salinity tolerance in rice

Article Info

\section{Accepted:}

18 January 2020

Available Online:

10 February 2020
Present investigation was carried out with 12 advanced $\left(\mathrm{M}_{7}\right)$ mutants developed using gamma rays on two varieties i.e., BPT-5204 and RP Bio-226 along with checks (Gangavati Sona and CSR-22) at Agricultural Research Station Gangavati, Karnataka state, India during kharif 2018. Analysis of variance revealed highly significant differences among the mutant lines for all morpho-physiological characters under study viz., Days to 50 per cent flowering, Plant height, Panicle length, Number of grains per panicle, Panicle weight, Productive tillers per hill, Length of flag leaf and Grain yield per plant. Higher magnitude of heritability (broad sense) and genetic advance as percentage of mean were observed for number of grains per panicle, productive tillers per hill, spikelet sterility, test weight, grain yield per plant, grain yield per ha and $\mathrm{Na}^{+} / \mathrm{K}^{+}$ratio indicating presence of additive gene action and fixation of genes. Correlation study revealed that grain yield per plant exhibited significant positive association with plant height, panicle length, number of grains per panicle and panicle weight at phenotypic level under saline stress condition. However, significant negative association was observed in case of days to fifty per cent flowering. Path analysis revealed that plant height, panicle length, panicle weight and length of flag leaf exhibited direct positive effect on grain yield per plant. Hence, it would be rewarding to lay stress on these characters in selection programme for increasing the yield and to screen for salinity tolerance.

\section{Introduction}

Rice (Oryza sativa L.) is the most important staple food crop for more than 60 per cent of the global population and forms the cheapest source of food, energy and protein. By origin, the crop is native to South East Asia with two cultivated (Oryza sativa and Oryza glaberrima) and 22 wild species. It belongs to the genus Oryza and grass family Poaceae. 
The crop is cultivated under a wide range of agro-ecological situations. Globally, it is grown in an area of 162.71 mha with an annual production of $741.47 \mathrm{mt}$ and productivity of $4556 \mathrm{~kg} \mathrm{ha}^{-1}$. It is the most important food crop of India with world ranking first in area (43.85 mha) and second to China in production (FAO, 2014). In India, rice is cultivated in an area of 43.49 mha with an annual production of $104.40 \mathrm{mt}$ and average productivity of $2400 \mathrm{~kg} \mathrm{ha}^{-1}$.

In Karnataka, it covers an area of 0.93 mha with a production of $3.01 \mathrm{mt}$ and average productivity of $2649 \mathrm{~kg} \mathrm{ha}^{-1}$ (Anonymous, 2017). The slogan- "Rice is life "is due to its overwhelming importance as staple food and also a source of livelihood for about 120-150 million rural households of the country. Rice is central to the lives of billions of people around the world. With the growth of world's population towards 10 billion by 2050 , the demand for rice will grow faster than for other crops.

A large number of factors such as drought, lodging, weeds, soil salinity, poor soil fertility, insect-pests, diseases, rodents etc., are responsible for the reduced quality and quantity of rice, among these salt-sensitivity being the major one. Millions of hectares in the humid regions of South and South-east Asia are technically suited for rice production but are left uncultivated or grown with low yields because of saline and problematic soils.

The extent of salt affected soils currently in India is $6.73 \mathrm{mha}$ in different agro-ecological regions, which is expected to increase to 16.2 million ha by 2050 (Anonymous, 2017). Tungabhadra Project (TBP) area is the major rice growing region in northern Karnataka with 3.5 lakh ha area under rice. Water logging and soil salinity in this command area is increasing over the years. Every year, salinity adds approximately 1000 ha to the salinity affected area and leads to drastic reduction in the paddy yields. Already one lakh hectare area is converted into saline stress soil. The popular cultivar in the area is BPT-5204 locally called Sambha Masuri/ Sona Masuri is a long duration variety, matures at around 140-150 days. This variety is excellent in grain quality and is better than other varieties in quality. BPT-5204 is suitable for growing in kharif season in TBP area under normal soils which occupied 90 per cent of the area. But its yield levels are lower in salt affected soils to the tune of 50 per cent. Therefore, there is an urgent need to develop salinity stress tolerant rice varieties having grain quality like BPT-5204 but with short duration. Accordingly, the mutation breeding programme was initiated and several early maturing and high yielding salt tolerant mutants of BPT-5204 and RP Bio-226 have been identified.

Genetic variability is of greatest interest to the plant breeder as it plays a vital role in framing successful breeding programme. Heritability of a metric character is a parameter of particular significance to the breeder as it measures the degree of resemblance between the parents and the offsprings and its magnitude indicates the heritability with which a genotype can be identified by its phenotypic expression, while genetic advance aids in exercising the necessary selection pressure.

\section{Materials and Methods}

The material for the study consisted of 12 rice mutants evaluated along with four checks under saline soil. The present investigation was conducted to study the variability and association among traits in the rice mutants under saline soil. The experiment was conducted at Agricultural Research Station (ARS), Gangavati during kharif 2018 in a Randomized Block Design (RBD) with three 
replications. Ten rows of each $4 \mathrm{~m}$ length were assigned to each genotype with plants having $20 \times 15 \mathrm{~cm}$ spacing.

All cultural practices were followed as per the package of practices adopted for irrigated rice, recommended by the University of Agricultural Sciences, Raichur. Soil samples from all the three replications were collected and they were analyzed for parameters such as $\mathrm{pH}$ and electrical conductivity (EC) using standard procedures.

Observations were recorded on five randomly selected plants in each replication for days to 50 per cent flowering, plant height, panicle length, number of grains per panicle, panicle weight, productive tillers per hill, length of flag leaf, spikelet sterility, test weight, grain yield per plant, grain yield per ha, length to breadth $(\mathrm{L} / \mathrm{B})$ ratio, $\mathrm{Na}^{+} / \mathrm{K}^{+}$ratio and amylose content.

Data for the above traits were subjected to statistical analysis viz., Analysis of variance (ANOVA), mean, range, genetic variability components such as phenotypic coefficient of variation (PCV), genotypic coefficient of variation $(\mathrm{GCV})$, heritability $\left(\mathrm{h}^{2}\right)$ and genetic advance as percent of mean (GAM). Correlation analysis was computed as per Karl Pearson (1932) and path coefficient analysis was carried out as suggested by Wright (1921).

\section{Results and Discussion}

Genetic variability in any crop is a prerequisite for selection of superior genotypes over the existing cultivars. Variance analysis for all the characters revealed significant variation among the genotypes studied and are represented in Table 1 . The variation in panicle length is depicted in Plate 1. The phenotypic coefficient of variation (PCV) in general was higher than genotypic coefficient of variation $(\mathrm{GCV})$ for all the characters studied indicated the influence of environment on the manifestation of these characters. However, the difference between PCV and GCV was less which indicated low environmental influence and predominance of genetic factors controlling variability in these traits.

The rice mutants exhibited high variability for two characters namely spikelet sterility (\%) and $\mathrm{Na}^{+} / \mathrm{K}^{+}$ratio. The estimates of $\mathrm{PCV}$ and GCV for spikelet sterility (\%) were 22.58 and 22.56 respectively. $\mathrm{Na}^{+} / \mathrm{K}^{+}$ratio exhibited PCV and GCV of 59.52 and 59.51 respectively.

Low amount of variability was also observed in some other traits. The PCV and GCV estimates for days to days to fifty per cent flowering were 7.73 and $7.63,9.75$ and 6.50 for plant height, 6.07 and 4.76 for panicle length, 7.38 and 4.91 for length of flag leaf, 8.93 and 6.86 for L/B ratio, 5.83 and 4.84 for amylose content.

The amount of genetic variation considered alone will not be of much use to the breeder unless supplemented with the information on heritability estimate, which gives a measure of the heritable portion of the total variation. It has been suggested by Burton and Devane (1953) that the GCV along with heritability estimate could provide a better picture of the amount of advance to be expected by phenotypic selection.

Since genetic advance is dependent on phenotypic variability and heritability in addition to selection intensity, the heritability estimates in conjunction with genetic advance will be more effective and reliable in predicting the response to selection (Johnson et al., 1955). Heritability in broad sense includes both additive and non-additive gene effects (Hanson et al., 1953). While, narrow 
sense heritability includes only additive components (Johnson et al., 1955). In the present study, heritability in broad sense was estimated. Heritability along with genetic advance is useful for selection. The estimates of heritability (\%) and genetic advance as per cent of mean (\%) were 98.29 and 45.85 for the trait number of grains per panicle, 95.14 and 20.58 for productive tillers per hill, 99.86 and 46.46 for spikelet sterility, 97.50 and 28.43 for test weight, 81.69 and 23.54 for grain yield per plant and 99.96 and 122.58 for $\mathrm{Na}^{+} / \mathrm{K}^{+}$ratio respectively.

These traits recorded high heritability (\%) coupled with high genetic advance over mean (\%) indicating the presence of additive gene action. The study clearly showed that there is ample scope to improve these traits through direct selection.

\section{Correlation between characters}

Selection for a specific character is known to result in correlated response in certain other characters (Falconer, 1964). Generally, plant breeders make selection for one or two attributes at a time, and then it becomes important to know the effect on other characters. Simple phenotypic correlation indicated broadly the type of association that exists between various attributes. The inter character correlation at phenotypic level among thirteen characters studied are presented in Table 2.

Under saline soil, grain yield per plant showed strong positive and highly significant phenotypic association with plant height (0.6193), panicle length (0.6143), number of grains per panicle $(0.3592)$ and panicle weight (0.4364). Similar findings were reported earlier by Krishnamurthy and Kumar (2012) for plant height, Gopikannan and Ganesh (2013) for panicle length, Rajamadhan et al., 2011 for number of grains per panicle and
Seetharaman (2009) for panicle weight. Whereas days to fifty per cent flowering (0.8414) showed strong negative and highly significant association with grain yield per plant. Similar result was also obtained by Pillai et al., (2011).

\section{Path coefficient analysis}

Path analysis furnishes information of influence of each contributing trait to yield under saline soil directly as well as indirectly and also enables the breeders to rank the genetic attributes according to their contribution. The direct and indirect effects of different yield components which were not revealed by correlation studies are partitioned by path analysis were given in Table 3 .

Four out of eight characters had positive and direct effect on grain yield per plant at phenotypic level. Length of flag leaf (0.0651) showed positive negligible effect. Plant height (0.2143) and panicle length (0.2972) showed moderate and positive effect. Panicle weight (1.3084) showed very high and positive effect on grain yield per plant. Similar results were obtained by Sivakumar and Kannan (2005) and Rita et al., (2006).

This indicates that, if other factors are held constant, an increase in panicle length and weight individually will reflect in increased yield, whereas character like days to days to fifty per cent flowering (-0.8020) showed high and negative effect.

Number of grains per panicle (-1.8538) and test weight $(-1.3210)$ showed very high and negative effect. Productive tillers per hill (0.0537 ) shows negligible and negative effect on grain yield per plant. The residual effect was found to be 0.4144 in path analysis. This indicated that other attributing characters were also important and may play a critical role in rice yield improvement. 
Table.1 Estimation of range, mean and different genetic parameters for yield and yield attributing characters of rice mutants

\begin{tabular}{|c|c|c|c|c|c|c|c|c|}
\hline \multirow[t]{2}{*}{ Character } & \multicolumn{3}{|c|}{ Range } & \multicolumn{2}{|c|}{$\begin{array}{c}\text { Co-efficient of variation } \\
(\%)\end{array}$} & \multirow{2}{*}{$\begin{array}{c}\mathbf{h}^{2}(\mathbf{b s}) \\
(\%)\end{array}$} & \multirow[t]{2}{*}{ GA @ 5\% } & \multirow[t]{2}{*}{$\operatorname{GAM}(\%)$} \\
\hline & Min & Max & Mean & PCV & GCV & & & \\
\hline DFF & 94.66 & 118.66 & 109.64 & 7.73 & 7.63 & 98.75 & 17.03 & 15.53 \\
\hline PH & 66.70 & 95.23 & 83.85 & 9.75 & 6.50 & 44.43 & 7.48 & 8.93 \\
\hline PL & 18.86 & 23.01 & 21.63 & 6.07 & 4.76 & 61.43 & 1.66 & 7.68 \\
\hline NGP & 98.51 & 184.46 & 154.82 & 14.63 & 14.50 & 98.29 & 45.85 & 29.62 \\
\hline PW & 1.85 & 2.77 & 2.37 & 10.88 & 10.06 & 85.53 & 0.45 & 19.17 \\
\hline PTH & 13.52 & 18.91 & 16.06 & 10.50 & 10.24 & 95.14 & 3.30 & 20.58 \\
\hline $\mathbf{L F}$ & 23.67 & 29.15 & 26.41 & 7.38 & 4.91 & 44.40 & 1.78 & 6.75 \\
\hline SS & 7.47 & 21.81 & 14.07 & 22.58 & 22.56 & 99.86 & 6.45 & 46.46 \\
\hline TW & 14.20 & 23.45 & 15.55 & 13.99 & 12.64 & 97.50 & 4.42 & 28.43 \\
\hline GYP & 9.09 & 25.83 & 13.14 & 14.15 & 13.97 & 81.69 & 3.09 & 23.54 \\
\hline YLD & 3030.66 & 5277 & 4381.66 & 13.99 & 12.65 & 81.68 & 1032 & 23.55 \\
\hline LBR & 2.66 & 3.66 & 2.91 & 8.93 & 6.86 & 59.01 & 0.316 & 10.86 \\
\hline SPR & 0.102 & 0.596 & 0.260 & 59.52 & 59.51 & 99.96 & 0.319 & 122.58 \\
\hline $\mathbf{A C}$ & 21.45 & 24.82 & 23.00 & 5.83 & 4.84 & 68.97 & 1.908 & 8.29 \\
\hline
\end{tabular}

DFF: Days to $50 \%$ flowering NGP: No. of grains per panicle LF: Length of flag leaf $(\mathrm{cm})$ GYP: Grain yield per plant (g) SPR: $\mathrm{Na}^{+}$to $\mathrm{K}^{+}$ratio
PH: Plant height $(\mathrm{cm})$ PW: Panicle weight (g) SS: Spikelet sterility YLD: Yield per ha
PL: Panicle length $(\mathrm{cm})$

PTH: Productive tillers per hill TW: Test weight (g)

LBR: Length to breadth ratio 
Table.2 Association (phenotypic correlation) among different quantitative traits in rice under saline soil

\begin{tabular}{|c|c|c|c|c|c|c|c|c|c|}
\hline & DFF & PH & PL & NGP & PW & PTH & $\mathbf{L F}$ & $\mathbf{T W}$ & GYP \\
\hline DFF & 1.000 & & & & & & & & \\
\hline PH & -0.5346 & 1.000 & & & & & & & \\
\hline PL & $-0.4230 * *$ & $0.4123 * *$ & 1.000 & & & & & & \\
\hline NGP & $-0.3287 *$ & 0.1311 & 0.2210 & 1.000 & & & & & \\
\hline PW & $-0.3742 * *$ & $0.3603 *$ & $0.4109 * *$ & $0.7294 * *$ & 1.000 & & & & \\
\hline PTH & -0.0407 & 0.1437 & -0.0609 & $-0.2889 *$ & -0.0414 & 1.000 & & & \\
\hline $\mathbf{L F}$ & 0.0055 & -0.0922 & -0.1880 & 0.0455 & -0.1567 & 0.0511 & 1.000 & & \\
\hline TW & -0.0595 & 0.2732 & 0.1737 & $-0.6683 * *$ & 0.0086 & $0.4051 * *$ & -0.2084 & 1.000 & \\
\hline GYP & $-0.8414 * *$ & $0.6193 * *$ & $0.6143 * *$ & $0.3592 *$ & $0.4364 * *$ & -0.0587 & -0.0317 & 0.0516 & 1.000 \\
\hline \multicolumn{3}{|c|}{ DFF: Days to $50 \%$ flowering } & \multicolumn{2}{|c|}{ PH: Plant height (cm) } & \multicolumn{3}{|c|}{ PL: Panicle length (cm) } & & \\
\hline \multicolumn{3}{|c|}{$\begin{array}{l}\text { NGP: No. of grains per panicle } \\
\text { LF: Length of flag leaf }(\mathrm{cm})\end{array}$} & \multicolumn{2}{|c|}{$\begin{array}{l}\text { PW: Panicle weight }(\mathrm{g}) \\
\text { TW: Test weight }(\mathrm{g})\end{array}$} & \multicolumn{3}{|c|}{$\begin{array}{l}\text { PTH: Productive tillers per hill } \\
\text { GYP: Grain yield per plant (g) }\end{array}$} & & \\
\hline
\end{tabular}


Table.3 Phenotypic path analysis for direct and indirect effects on grain yield per plant in rice genotypes

\begin{tabular}{|c|c|c|c|c|c|c|c|c|}
\hline & DFF & $\mathbf{P H}$ & PL & NGP & PW & PTH & LF & TW \\
\hline DFF & -0.8020 & 0.4288 & 0.3393 & 0.2636 & 0.3001 & 0.0326 & -0.0044 & 0.0477 \\
\hline $\mathbf{P H}$ & -0.1145 & 0.2143 & 0.0883 & 0.0281 & 0.0772 & 0.0308 & -0.0198 & 0.0585 \\
\hline PL & -0.1257 & 0.1225 & 0.2972 & 0.0657 & 0.1221 & -0.0181 & -0.0559 & 0.0516 \\
\hline NGP & 0.6093 & -0.2430 & -0.4097 & -1.8538 & -1.3521 & 0.5356 & -0.0844 & 1.2388 \\
\hline PW & -0.4896 & 0.4714 & 0.5376 & 0.9543 & 1.3084 & -0.0541 & -0.2050 & 0.0112 \\
\hline PTH & 0.0022 & -0.0077 & 0.0033 & 0.0155 & 0.0022 & -0.0537 & -0.0027 & -0.0217 \\
\hline $\mathbf{L F}$ & 0.0004 & -0.0060 & -0.0122 & 0.0030 & -0.0102 & 0.0033 & 0.0651 & -0.0136 \\
\hline TW & 0.0786 & -0.3609 & -0.2294 & 0.8828 & -0.0113 & -0.5351 & 0.2753 & -1.3210 \\
\hline GYP & -0.8414 & 0.6193 & 0.6143 & 0.3592 & 0.4364 & -0.0587 & -0.0317 & 0.0516 \\
\hline
\end{tabular}

Residual effect: 0.4144

R SQUARE: 0.8282

DFF: Days to $50 \%$ flowering NGP: No. of grains per panicle LF: Length of flag leaf $(\mathrm{cm})$
PH: Plant height $(\mathrm{cm})$

PW: Panicle weight $(\mathrm{g})$

TW: Test weight $(\mathrm{g})$
PL: Panicle length $(\mathrm{cm})$

PTH: Productive tillers per hill

GYP: Grain yield per plant (g) 

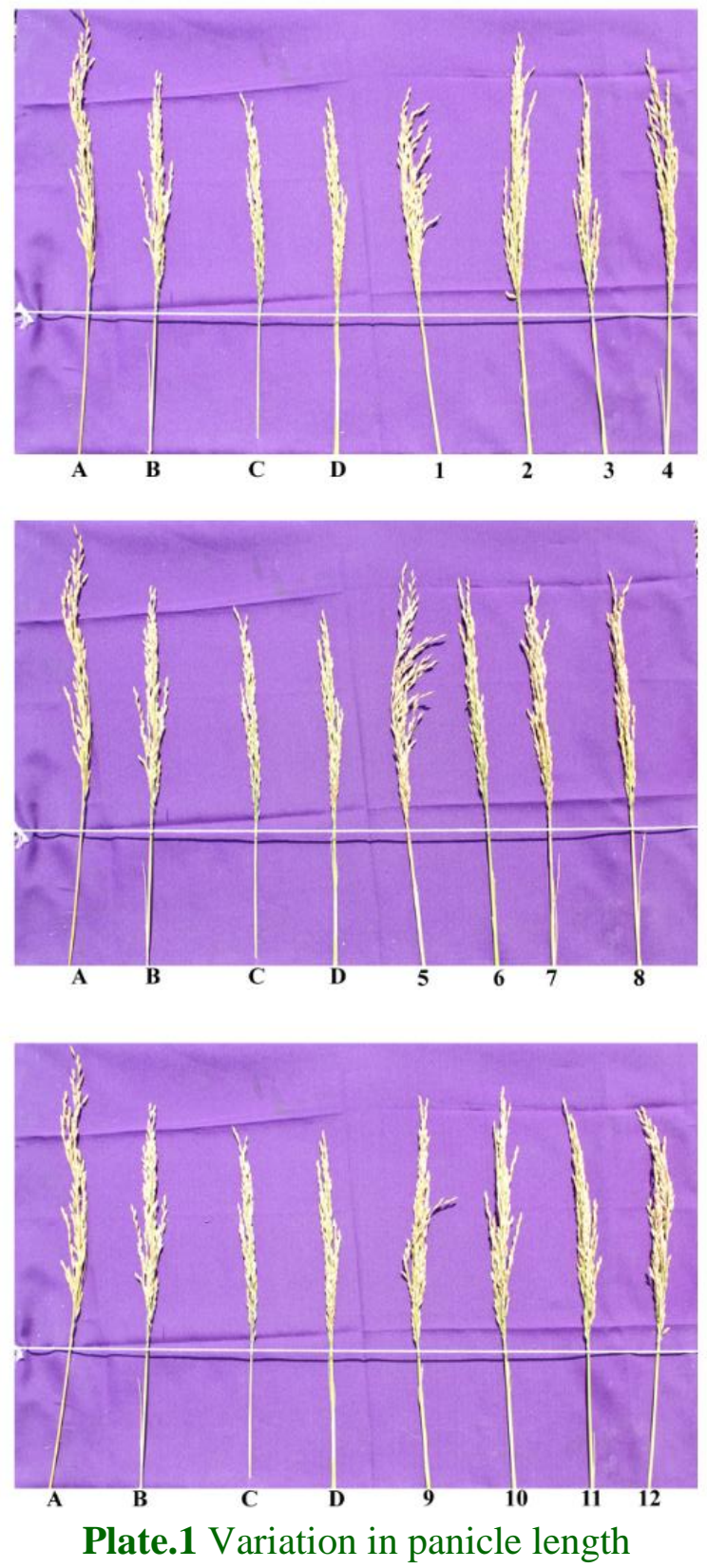
A: CSR-22
B: Gangavati Sona
C: RP Bio-226
D: BPT-5204
1: BPT-5204 Mutant 601
3: BPT-5204 Mutant 609
5: RP Bio-226 Mutant 615
7: BPT-5204 Mutant 626
9: BPT-5204 Mutant 638
11: BPT-5204 Mutant 653
2: BPT-5204 603
4: RP Bio-226 Mutant 614
6: RP Bio-226 Mutant 618
8: BPT-5204 Mutant 633
10: BPT-5204 Mutant 619
12: BPT-5204 Mutant 1807 
Direct yield improvement under saline condition is difficult. Hence, yield improvement in salt stress environments could be achieved by identifying secondary traits contributing to salt tolerance and selecting those traits in a breeding programme.

Commencing the experimental findings it could be accomplished that most of the characters were governed by additive gene action such as number of grains per panicle, productive tillers per hill, spikelet sterility, test weight, grain yield per plant and $\mathrm{Na}^{+} \mathrm{K}^{+}$ ratio indicates that these traits are least influenced by environment hence selection may be effective through these characters.

Grain yield per plant exhibited a very strong positive association with plant height, panicle length, number of grains per panicle and panicle weight at phenotypic level which indicated that these traits were the strongest associates of grain yield per plant. Path analysis identified that plant height, panicle length, panicle weight and length of flag leaf as major direct contributors.

Thus a genotype with higher magnitude of these traits could be either selected from existing genotypes or evolved by breeding program for genetic improvement of yield in rice. Further the occurrence of negative as well as positive indirect effects by yield components on grain yield via one or the other character simultaneously, presents a complex situation where a compromise is required to attain proper balance of different yield components in determining ideotype for high grain yield for salt affected soils in rice.

\section{References}

Anonymous, 2017, Selected state/season wise area, production and productivity of rice in India, Ministry of Agriculture and
Farmers welfare, Govt. of India, www.Indiastat.com.

Burton, G. W. and Devane, E. M., 1953, Estimating heritability in tall fescue (Festuca, circunc L.) from replicated clonal material. Agron. J., 45: 478-481.

Falconer, D.S., 1964, Introduction to quantitative genetics. Oliver and Boyd, London, p:365.

Food and Agriculture Organization (FAO), 2014, www.fao.org.in.

Gopikannan, M. and Ganesh, S. K., 2013, Inter-relationship and path analysis in rice (Oryza sativa L.) under sodicity. Indian J. Sci. Technol., 6(9): 52235227.

Hanson, G. H., Robinson, H. F. and Comstack, R. E., 1953, Biometrical studies of yield in segregating populations of Korian Lespedeza. Agron. J., 48: 267-282.

Johnson, H. W., Robinson, H. F. and Comstock, R. E., 1955, Estimates of genetic and environmental variability in soybean. Agron. J., 47: 314-318.

Karl Pearson, 1932, Tables for statisticians and biometricians. Stat .J. Biometrics.

Krishnamurthy, H. T. and Kumar, H. D. M., 2012, Correlation and path coefficient studies of some physiological traits among indigenous aromatic rice (Oryza sativa L.) cultivars. Agril. Bio. Res., 28 (2): 120- 127.

Rajamadhan, R. R., Eswaran, and Anandan, A., 2011, Investigation of correlation between traits and path analysis of rice (Oryza sativa L.) grain yield under coastal salinity. Electronic J. of Plant Breed., 2(4): 538-542.

Rita, B., Motiramani, N. K. and Sarwgi, 2006, Association analysis and variability analysis in rice. Mysore J. Agric. Sci., 40(3): 375-380.

Seetharam, K., Thirumeni, S. and Paramasivam, K., 2009, Estimation of genetic diversity in rice (Oryza sativa 
L.) genotypes using SSR markers and morphological characters. African $J$. Biotech. 8(10): 2050-2059.

Sivakumar, P. and Kannan, B. J. R., 2005, Character association in inter sub- specific rice hybrids involving wide compatible gene. Crop Res., 30(2): 208210.

Wright, S., 1921, Correlation and causation. J. Agric. Res., 20: 557-585.

\section{How to cite this article:}

Prashanth. C, K. Mahantashivayogayya, J. R. Diwan, P. H. Kuchanur and Vishwanath. J. 2020. Genetic Variability and Association Studies on Bpt-5204 Based Rice Mutants under Saline Stress Soil. Int.J.Curr.Microbiol.App.Sci. 9(02): 2441-2450.

doi: https://doi.org/10.20546/ijcmas.2020.902.279 